KEYWORDS

Ports

Cargo

Container terminals

Maritime transport

Productivity

Measurement

Mathematical models

Mexico
CEPAL REVIEW 99 • DECEMBER 2009

\section{Mexico: total productivity changes at the principal container ports}

$\mathbf{P}$

ort performance is commonly measured using partial productivity indicators obtained by relating an output to an input. To ascertain the overall productivity of a port, however, it is more helpful to employ the concept of total productivity, which considers all the inputs employed to obtain the totality of outputs. This factor has been measured using the Malmquist index, which gives the change in total factor productivity (TFP). The present study uses this index to determine the change in the TFP of the principal container ports in Mexico. According to the results obtained, productivity gains were greater at medium-sized terminals such as Progreso and Ensenada than at hubs such as Veracruz and Altamira, even though the latter are more efficient.

Alejandro Guerrero C

Researcher, Mexican Institute of Transport

- aguerrero@imt.mx

César Rivera T.

Lead researcher, Mexican Institute of Transport

$\infty$ crivera@imt.mx 


\section{I}

\section{Introduction}

Ports carry out activities of great importance for external trade. Consequently, measuring the performance of these activities is the first duty of any port authority. In Mexico, port performance is quantified by relating a quantity of output with a quantity of input, such as tonnage handled per crane or tons per shiphour in port. These indicators are known as partial productivity indicators.

The use of partial indicators is helpful for comparing performance between port activities; they are not so useful, however, when it comes to ascertaining the overall productivity of the port. Accordingly, some researchers have suggested using the concept of total factor productivity (TFP) in the port industry.

TFP is obtained by relating the totality of outputs to the totality of inputs employed in the production process. This measure has only recently been applied to the port sector and the technique most employed has been the Malmquist index, which can measure the change in TFP over different periods. This index can also be used to measure changes in each of the components of total productivity: technical efficiency, technological change and production scale efficiency. This allows the causes of possible inefficiencies to be ascertained in greater detail.

Understanding how the productivity of a port has behaved over recent years is crucial if the right measures are to be taken to correct the inefficiencies detected, and will enhance the port's strengths. Consequently, the objective of this study is to determine how the total factor productivity of the principal container ports in Mexico has changed.

To achieve this objective, the article is divided into six sections. This Introduction briefly presents the problem. Section II presents the differences between the concepts of efficiency and productivity and the methodology that will be used to develop the model for obtaining TFP. Section III describes cargo flows in Mexican ports and gives a presentation of container traffic. Apart from the sample of ports to be analysed, a decisive factor in obtaining consistent results is the selection of the outputs and inputs that will make up the sample; this is dealt with in section IV. The results obtained in the course of this study are presented in section V. Lastly, section VI offers conclusions.

\section{II}

\section{Defining productivity and efficiency}

In seeking to quantify the performance of some industry, be it public or private, the concepts of productivity and technical efficiency are commonly used. These concepts are very often - and mistakenlyused without distinction. According to González and Trujillo (2005), the confusion derives from the fact that the more efficient and productive a firm is, the better it performs. While the concepts are closely related, however, they should not be treated alike.

Productivity is defined as the ratio between the volume produced (outputs) and the resources employed to produce it (inputs), while measures of technical efficiency compare observed output with its optimal values. Again, while productivity measures the performance of a production process in the round, efficiency is a component of productivity.
To further clarify the differences between productivity and efficiency, we need to refer to the work of Farrell (1957), considered the precursor of modern efficiency measures. According to Farrell, technical efficiency will tell us whether the resources and technology available are being properly used.

Thus, to quantify technical efficiency it will be necessary to take one or another of the following approaches:

- Output orientation: with this approach, the primary objective will be to measure efficiency by considering the maximum output attainable with a given quantity of inputs.

- Input orientation: here, the standard against which efficiency is measured is the minimum combination of inputs possible for a given output. 
Thus, determining efficiency requires a comparative framework that is known as the production frontier, representing the maximum output achievable with the technology available. Farrell suggested that the production frontier should be established on the basis of the highest observed efficiencies, thus employing the concept of benchmarking.

For a better grasp of the above, it is helpful to consider a production process in which just one input is used to produce an output. The relationship between output quantity and input quantity can be interpreted graphically, as we see in figure 1, where the OF curve represents the production frontier. Efficiency will be defined by comparing observed output to this frontier, i.e., firms operating over the frontier will be deemed technically efficient.

For example, if a firm operates at point $\mathrm{A}$ of figure 1, it is easy to deduce that it is inefficient, as it could increase its output to point B using the same quantity of inputs, or produce the same amount from fewer inputs (point C). According to the definition of productivity analysed previously, this is represented by the slope of the straight line that runs from the origin and passes through the point concerned. Thus, it can be observed that efficient firms are also more productive since, as figure 1 shows, the straight lines $\mathrm{OB}$ and $\mathrm{OC}$ (efficient points) slope more steeply than OA.

Likewise, productivity cannot be increased simply by improving technical efficiency. For example, introducing new technologies into a port by acquiring faster, larger-capacity cranes will shift the production frontier, thereby raising productivity. This is represented graphically in figure 2, where curve OF1 shows the situation arrived at by employing new technologies, and we see that productivity is higher at OD' than at OD.

The last factor affecting productivity is the scale on which production takes place. Observing points A and $B$ in figure 2, we can see that both are efficient, but productivity is greater at $\mathrm{B}$ than $\mathrm{A}$ since the slope is steeper. Consequently, a firm wishing to be more productive will have to adjust its output to point $\mathrm{B}$.

In summary, improving technical efficiency, producing at an appropriate scale (scale efficiency) and introducing new technologies (technological change) will have a positive effect on port productivity. These

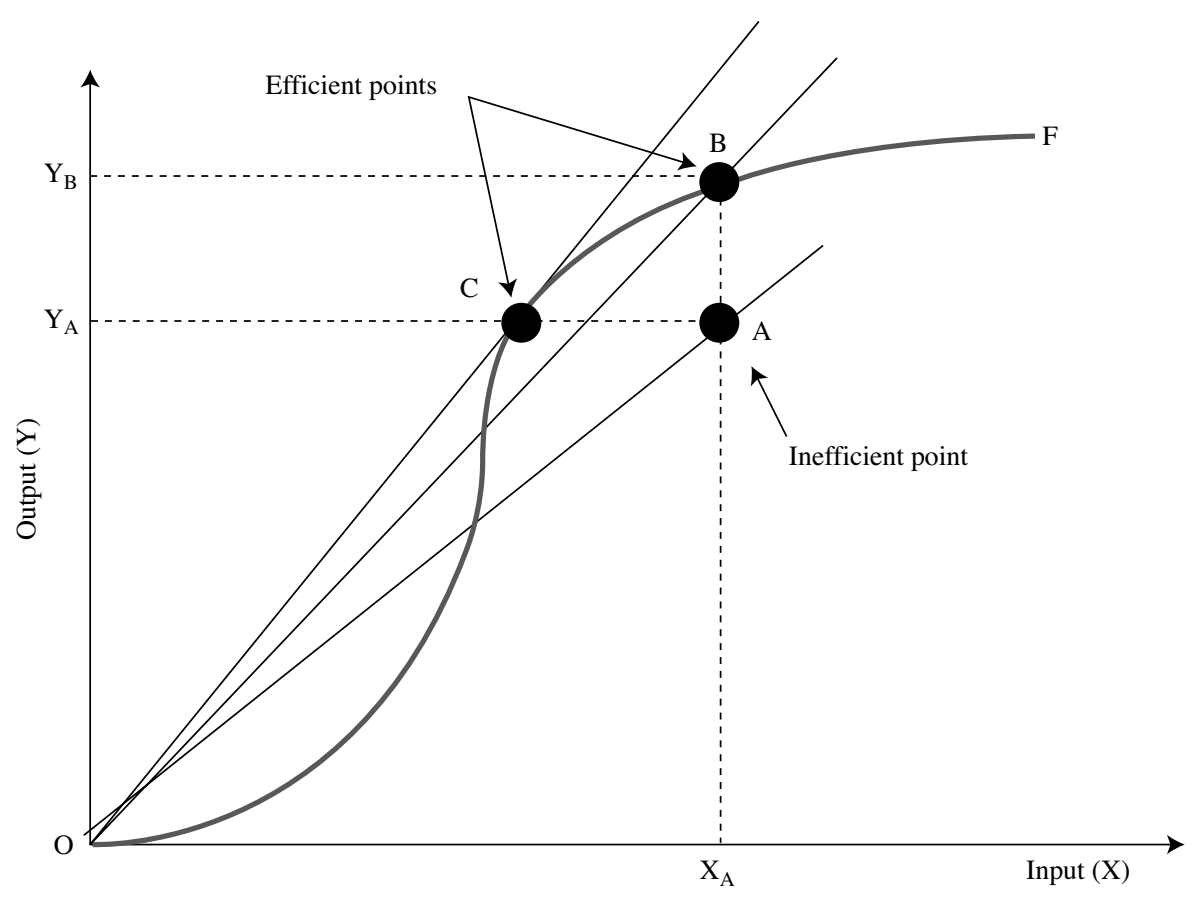

Source: T. Coelli, D.S. Prasada Rao and G.E. Battese, An Introduction to Efficiency and Productivity Analysis, Boston, Kluwer Academic Publisher, 1998. 
FIGURE 2

Productivity, technical efficiency and production scale

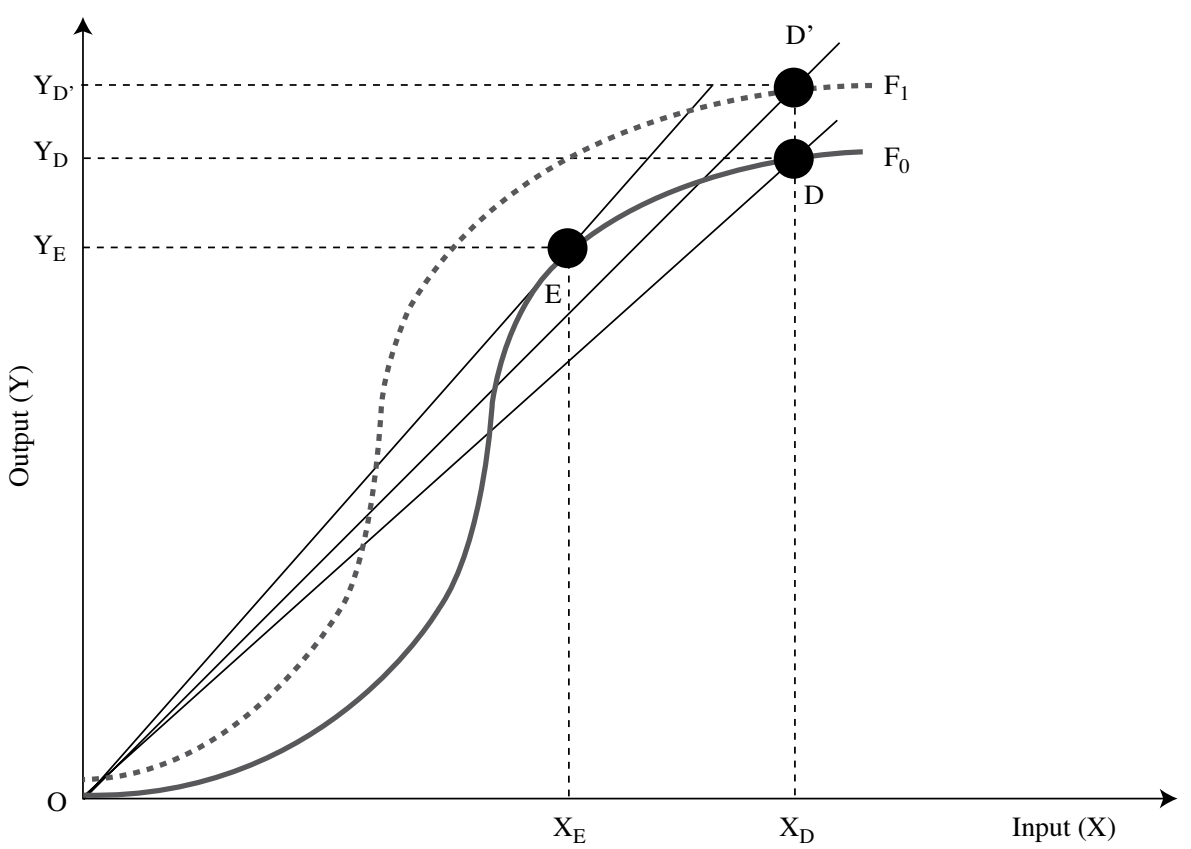

Source: T. Coelli, D.S. Prasada Rao and G.E. Battese, An Introduction to Efficiency and Productivity Analysis, Boston, Kluwer Academic Publisher, 1998.

three factors are known as productivity components, and they are indispensable for determining total factor productivity (TFP), which it is the purpose of this paper to obtain.

The methodology employed to measure changes in TFP is the Malmquist index, which will be described further on. This index is defined using distance functions to describe a multi-input and multi-output technology without the need for any particular behaviour target such as minimizing costs or maximizing benefits (Coelli, Prasada Rao and Battese, 1998).

This paper uses an output-oriented distance function, a technology whose purpose is to maximize the output of an input vector. In other words, the port authority obtains the greatest utility by using its existing infrastructure and equipment more efficiently, maximizing the quantity of twenty-foot equivalent units (TEUs) handled.

\section{Changes in total factor productivity}

As Estache, Tovar de la Fe and Trujillo (2004) note, port productivity, more than any other type of transport-related productivity, is related back to partial indicators. In other words, port authorities usually measure their performance by relating the tonnage handled to the number of cranes or the number of ships turned round per unit of time. These indicators are very useful for ascertaining the productivity of a particular area of the port, but are not well suited to determining overall productivity.

Given the limitations of partial indicators, economists have mainly concentrated on measures of productivity like comparisons of changes in total outputs associated with changes in total inputs, giving rise to the concept of total factor productivity (TFP), which is defined as the ratio between some function that adds outputs and some function that adds inputs (González and Trujillo, 2005).

Mathematically, this is equivalent to applying the corresponding additions in the productivity ratio, whereby the following expression is obtained:

$$
T F P=\frac{\sum_{m=1}^{M} u_{m}^{\prime} y_{m}}{\sum_{k=1}^{K} v_{k}^{\prime} x_{k}}
$$


where $T F P$ is total factor productivity for $M$ products employing $K$ inputs and $u^{\prime}$ and $v^{\prime}$ are weights, since not all inputs or outputs can be equally important.

Consequently, the change in total productivity can be estimated as the ratio of the change in TFP over a period of analysis. To clarify this, we shall once again take the example of a firm that produces one output and employs one input for the purpose. The expression that tells us how productivity changed between a starting period $(t)$ and a final period $(t+1)$ is:

$$
\frac{y_{t+1} / x_{t+1}}{y_{t} / x_{t}}
$$

Expression (2) has two peculiarities. The first, which has already been remarked upon, is that it can only be used for production processes involving one output and one input. The second is that it only compares productivity levels observed in two periods, assuming that the technology has remained constant.

To solve this, use has been made of the Malmquist index proposed by Caves, Christensen and Diewert (1982). This index employs the distance functions introduced by Shephard (1953) to determine the distance between the entities compared and the most efficient ones.

The Malmquist productivity index has been represented by the following function:

$$
M_{o c}^{t}\left(x^{t}, y^{t}, x^{t+1}, y^{t+1}\right)=\frac{D_{o c}^{t}\left(x^{t+1}, y^{t+1}\right)}{D_{o c}^{t}\left(x^{t}, y^{t}\right)}
$$

where $M_{o c}^{t}\left(x^{t}, y^{t}, x^{t+1}, y^{t+1}\right)$ compares $\left(x^{t+1}, y^{t+1}\right)$ with $x^{t}, y^{t}$, obtaining the distance between them and the best possible benchmark given the technology of period $t$, i.e., $T_{c}^{t}$. Thus, a value greater than 1 in expression (3) would indicate that the value of TFP has increased, whereas the opposite is true of values below 1 .

Similarly, the corresponding ratio can be determined taking the technology of period $t+1$ as the base, i.e., $T_{c}^{t+1}$, which gives the expression:

$$
M_{o c}^{t+1}\left(x^{t}, y^{t}, x^{t+1}, y^{t+1}\right)=\frac{D_{o c}^{t+1}\left(x^{t+1}, y^{t+1}\right)}{D_{o c}^{t+1}\left(x^{t}, y^{t}\right)}
$$

Thus, expressions (3) and (4) assume that the technology remains the same at times $t$ and $t+1$. Caves, Christensen and Diewert (1982) argued that changes in technology could be determined by calculating the geometric mean of the expressions above, whence the Malmquist index:

$$
\begin{gathered}
M_{o c}\left(x^{t}, y^{t}, x^{t+1}, y^{t+1}\right)= \\
{\left[\frac{D_{o c}^{t}\left(x^{t+1}, y^{t+1}\right)}{D_{o c}^{t}\left(x^{t}, y^{t}\right)} \times \frac{D_{o c}^{t+1}\left(x^{t+1}, y^{t+1}\right)}{D_{o c}^{t+1}\left(x^{t}, y^{t}\right)}\right]^{1 / 2}}
\end{gathered}
$$

The Malmquist index can be represented graphically if we once again consider the process of producing one output with one input. Figure 3 shows the "distances" that will need to be obtained to measure the change in productivity that took place between point $\mathrm{E}(t+1)$ and $\mathrm{D}(t)$, taking the technologies of the two periods as frontiers.

Consequently, the change in technical efficiency and technological change would be determined by the following expressions:

Change in technical efficiency $=\frac{y_{t+1} / y_{c}}{y_{t} / y_{a}}$
Technological change $=\left[\frac{y_{t+1} / y_{b}}{y_{t+1} / y_{c}} \times \frac{y_{t} / y_{a}}{y_{t} / y_{b}}\right]^{1 / 2}$

Thus, as argued by Coelli, D.S. Prasada Rao and G.E. Battese (1998), an equivalent way of writing equation (5) is:

$$
\begin{gathered}
M_{o c}\left(x^{t}, y^{t}, x^{t+1}, y^{t+1}\right)=\frac{D_{o c}^{t}\left(x^{t+1}, y^{t+1}\right)}{D_{o c}^{t}\left(x^{t}, y^{t}\right)} \\
{\left[\frac{D_{o c}^{t}\left(x^{t+1}, y^{t+1}\right)}{D_{o c}^{t+1}\left(x^{t+1}, y^{t+1}\right)} \times \frac{D_{o c}^{t}\left(x^{t}, y^{t}\right)}{D_{o c}^{t+1}\left(x^{t}, y^{t}\right)}\right]^{1 / 2}}
\end{gathered}
$$

In equation (6), the ratio outside the square brackets represents the change in technical efficiency, while everything inside the brackets is technological change.

To estimate the four measures of the distance given in equation (5), both econometric and linear programming methods are used. The present paper employs data envelopment analysis (DEA), based on linear programming techniques. 
FIGURE 3

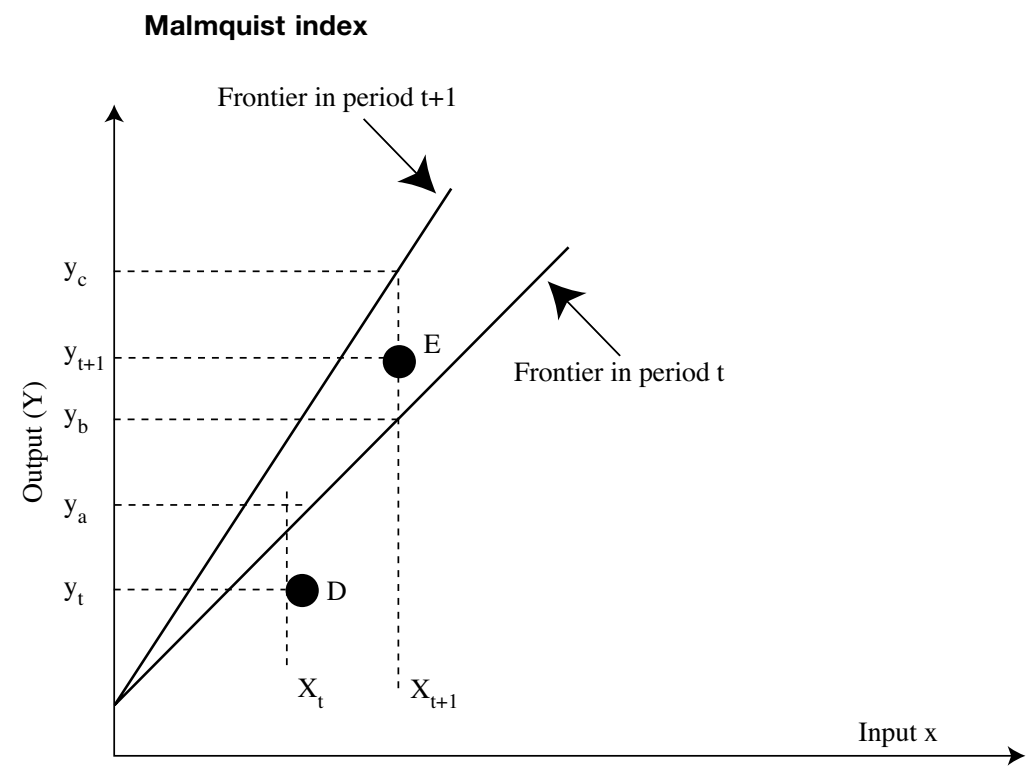

Source: T. Coelli, D.S. Prasada Rao and G.E. Battese, An Introduction to Efficiency and Productivity Analysis, Boston, Kluwer Academic Publisher, 1998.

To address problems of linear programming, Fare and others (1994) assumed a constant scale of return and had the following linear programming problems:

$$
\begin{aligned}
& {\left[d_{0}^{t}\left(x_{t}, y_{t}\right)\right]^{-1}=\max _{\phi, \lambda} \phi,} \\
& \text { sa }-\phi y_{i t}+Y_{t} \lambda \geq 0 \text {, } \\
& x_{i t}-X_{t} \lambda \geq 0 \text {, } \\
& \lambda \geq 0 \\
& {\left[d_{0}^{t+1}\left(x_{t+1}, y_{t+1}\right)\right]^{-1}=\max _{\phi, \lambda} \phi,} \\
& \text { sa }-\phi y_{i, t+1}+Y_{t+1} \lambda \geq 0 \text {, } \\
& x_{i, t+1}-X_{t+1} \lambda \geq 0 \text {, } \\
& \lambda \geq 0 \\
& {\left[d_{0}^{t}\left(x_{t+1}, y_{t+1}\right)\right]^{-1}=\max _{\phi, \lambda} \phi,} \\
& \text { sa }-\phi y_{i, t+1}+Y_{t} \lambda \geq 0 \text {, } \\
& x_{i, t+1}-X_{t} \lambda \geq 0 \text {, } \\
& \lambda \geq 0 \\
& {\left[d_{0}^{t+1}\left(x_{t}, y_{t}\right)\right]^{-1}=\max _{\phi, \lambda} \phi,} \\
& \text { sa }-\phi y_{i t}+Y_{t+1} \lambda \geq 0 \text {, } \\
& x_{i t}-X_{t+1} \lambda \geq 0 \text {, } \\
& \lambda \geq 0
\end{aligned}
$$


to those that have employed the Malmquist index to measure changes in total productivity.

Estache, Tovar de la Fe and Trujillo (2004) measured changes in TFP in twelve Mexican ports. The objective of that study was to ascertain whether the introduction of private-sector capital had brought improvements in the productivity and efficiency of Mexican ports. The choice both of the period for analysis and of the inputs and outputs employed took account of this objective; since private-sector capital began to be introduced between 1996 and 1999 , they considered that this period would yield accurate conclusions. The output selected was tonnage handled, while inputs were represented by the length of docks available to the Integral Port Administration (API) and the number of workers it employed. The findings showed that there had been gains in TFP at the great majority of ports, with only Topolobambo and Tampico showing a decline.

In a second study, Liu, Liu and Cheng (2006) applied the Malmquist index and ascertained the change in TFP for a good many container terminals in China. This study is important because ports in Asia, and China in particular, have grown substantially over the present decade and have been displacing North American and European ports in container traffic. According to the study cited, the container terminals with the highest levels of activity improved their TFP, while the opposite happened at small terminals.

The results of the Malmquist index have been a topic of discussion in various areas, since as Coelli, Prasada Rao and Battese (1998) argue, the assumption of a constant scale of returns can lead to errors when calculating changes in efficient scale, given that in practice it is more common to assume a variable scale of returns.

Again, there are a number of considerations to be taken into account when applying this index to the complex port sector since, as Doerr and Sánchez (2006) mention, it is difficult to quantify all activities using just one indicator.

\section{III}

\section{The Mexican port system}

The system comprises 114 ports, of which only 26 handle ocean-going cargoes, i.e., they are foreign trade ports which we can classify into three groups:

Hub ports. These account for the bulk of ocean-going traffic; in 2007, Veracruz, Altamira, Lázaro Cárdenas and Manzanillo handled $64.8 \%$ of the total.

Secondary ports. These handle less cargo than the above in their role as hubs, but have a substantial market share and possess terminals capable of handling almost every type of cargo. Ensenada, Tampico, Coatzacoalcos and Progreso are in this group.

Ports that act as hubs for a single cargo type. These are specialized terminals for particular goods, such as Isla de Cedros, Isla San Marcos, Punta Santa María and Punta Venado.

Since port liberalization in 1993 , the main ports have increased their market share thanks to the competitive advantages they enjoy. Traffic was less concentrated prior to liberalization, particularly at the Pacific ports, where in the late 1980s the likes of Guaymas, Mazatlán and Salina Cruz gave balance to container handling, which is now dominated by Manzanillo and Lázaro Cárdenas.
As Martner (2002) notes, the situation is somewhat different in the Gulf of Mexico, since cargo handling at its ports has always been quite heavily concentrated; the historical importance of Veracruz and Tampico always gave them a preponderance over other terminals. The great change after port liberalization came with the incorporation of the port of Altamira, which gradually displaced Tampico as a cargo hub, particularly where containers were concerned.

In summary, it transpires that the four Mexican ports handling the most cargo overall also handle the most container cargo, these being Manzanillo and Lázaro Cárdenas on the Pacific seaboard and Veracruz and Altamira on the Gulf of Mexico. These four ports have achieved this positioning in the Mexican market because they serve not just the urban centres close to them, but also other regions for which geographical proximity is not such an issue because they have a multiregional system of transport connections.

The concentration of container handling at these ports goes back a long way. Veracruz was the national leader in cargo movements of this type until 2001. 
Trade with Asia began to grow substantially from that time on, so that the port of Manzanillo became the busiest. As already mentioned, Altamira gradually left Tampico behind; in 2000, Altamira handled just over 3.5 times as many containers as Tampico, whereas by
2007 it was handling almost 36 times as many. As for Lázaro Cárdenas, while it handled fewer containers than the other three hub ports in 2007, its growth since 2003 has been substantial. The figures for container traffic are given in table 1.

TABLE 1

Mexican ports: container cargo handled, 2000-2007 $\left(\right.$ TEUs $\left.{ }^{a}\right)$

\begin{tabular}{|c|c|c|c|c|c|c|c|c|}
\hline Port & 2000 & 2001 & 2002 & 2003 & 2004 & 2005 & 2006 & 2007 \\
\hline Pacific & 477658 & 505668 & 704800 & 773861 & 928204 & 1098447 & 1564173 & 1830387 \\
\hline Ensenada & 26822 & 26016 & 53142 & 46332 & 39202 & 75101 & 123711 & 120324 \\
\hline San Carlos & 362 & - & - & - & - & - & - & - \\
\hline Pichilingue & 362 & - & - & - & - & - & - & 28 \\
\hline Guaymas & 498 & - & 33 & 2 & - & - & 25 & 4 \\
\hline Mazatlán & 16813 & 18315 & 12900 & 16394 & 15954 & 17559 & 30111 & 29363 \\
\hline Manzanillo & 426717 & 458472 & 638507 & 708417 & 829603 & 872386 & 1249630 & 1409614 \\
\hline Lázaro Cárdenas & 752 & - & 134 & 1646 & 43445 & 132479 & 160696 & 270240 \\
\hline Salina Cruz & 5332 & 2865 & 84 & 1070 & - & 922 & - & 734 \\
\hline Puerto Chiapas & - & - & - & - & - & - & - & 80 \\
\hline Gulf and Caribbean & 835841 & 847430 & 858228 & 910580 & 974356 & 1034766 & 1112518 & 1232033 \\
\hline Altamira & 182545 & 206864 & 225937 & 256417 & 297017 & 324601 & 342656 & 407657 \\
\hline Tampico & 49472 & 29531 & 18848 & 14347 & 9862 & 9001 & 10243 & 11040 \\
\hline Tuxpán & 104 & 341 & 276 & 58 & 1 & 15 & 24 & 8 \\
\hline Veracruz & 540014 & 543327 & 548422 & 571867 & 591736 & 620858 & 674872 & 729717 \\
\hline Dos Bocas & - & - & - & 64 & 150 & 265 & 46 & 80 \\
\hline Seybaplaya & - & - & - & - & - & 12 & 98 & 5 \\
\hline Progreso & 56581 & 60117 & 57787 & 60312 & 68082 & 71769 & 75692 & 75584 \\
\hline Puerto Morelos & 7125 & 7250 & 6958 & 7515 & 7508 & 8245 & 8887 & 7942 \\
\hline
\end{tabular}

Source: prepared by the authors on the basis of data from the Department of Ports and the Merchant Navy of the Secretariat of Communications and Transport.

a Twenty-foot equivalent units.

\section{IV}

\section{Data sample for the study}

A port's productivity is difficult to measure because of the array of actors and interests that meet together there. For example, a port provides a wide variety of services, such as cargo transfer from one mode of transport to another, cargo consolidation and deconsolidation and ship servicing. The inputs and outputs selected will depend on which service is to be analysed.

In the present study, we consider that the main function of a port is to move merchandise, so that the output selected was the amount of containers handled by the port. On this basis, the ports selected were those with a continuous record of container handling, namely Ensenada, Mazatlán and Manzanillo on the Pacific seaboard and Altamira, Tampico, Veracruz and Progreso on the Gulf.

The decision was taken not to include Lázaro Cárdenas in the sample because it was an outlier. In the starting year for the sample (2000), TEU throughput at this port was practically nil, whereas in 2007 the 
port's container traffic represented about $9 \%$ of the total. The extraordinary growth recorded by this port causes a deviation in the sample, making its inclusion unadvisable.

Again, when selecting inputs it is necessary to bear in mind that they have to represent the three basic inputs employed in the production function, namely land, labour and capital. The port infrastructure data are very representative of the land and capital inputs, represented in the present study by storage area and length of docks, respectively. As for labour, consideration was given to the possibility of including the number of workers at the port; this information is not easy to obtain, however, so this input was represented by the amount of equipment owned by the port, since according to Herrera and Pang (2005), there is a close relationship between the number of workers and the amount of equipment in a port.

Ports have a great variety of equipment, but containers are basically moved by yard and dockside gantry cranes, and it is these that are used as inputs in the present study.

The analysis was carried out for the period between 2000 and 2007. A sample of seven ports was covered for a period of eight years, using four inputs and one output so that, given the methodology employed, we consider the data panel acceptable for the objective of this study.

\section{V}

\section{Changes in total factor productivity (TFP)}

As already noted, the Malmquist index can be used to obtain changes not just in TFP, but also in each of the components of productivity, namely technical efficiency, production scale efficiency and technological change. The Data Envelopment Analysis Program (Coelli, 1996) was used for the present study.

The change in TFP showed an improvement in almost all the ports analysed since all the ports other than Veracruz and Tampico presented improvements in TFP. Table 2 shows the cumulative index of change in TFP. To obtain this table, the starting point taken was the first productivity value obtained and productivity changes observed in subsequent periods were measured from this base, so that a value under 1 indicates falling productivity and a value over 1 rising productivity.

The interpretation of the results is presented in figure 4, which shows that Progreso is the port with the highest value, followed by Ensenada and Manzanillo. It should be stressed that the values given in figure 4 are not a comparative measure of the productivity levels observed in each port but the cumulative change in total productivity over the period analysed. The starting value is therefore 1 for each port, and changes in total productivity are measured in relation to this.

TABLE 2

Cumulative index of change in port TFPa

\begin{tabular}{lccccccc}
\hline Year & Ensenada & Mazatlán & Manzanillo & Altamira & Tampico & Veracruz & Progreso \\
\hline 2000 & 1 & 1 & 1 & 1 & 1 & 1 & 1 \\
2001 & 0.963 & 1.059 & 1.073 & 1.131 & 0.612 & 1.006 & 1.440 \\
2002 & 1.887 & 0.765 & 1.297 & 1.235 & 0.387 & 0.921 & 1.073 \\
2003 & 1.638 & 0.941 & 1.437 & 0.862 & 0.286 & 0.962 & 1.459 \\
2004 & 1.389 & 0.941 & 1.685 & 1 & 0.204 & 0.754 & 1.653 \\
2005 & 1.068 & 1.059 & 1.717 & 1.094 & 0.183 & 0.791 & 1.751 \\
2006 & 1.766 & 1.765 & 2.070 & 1.010 & 0.102 & 0.860 & 2.771 \\
2007 & 2.128 & 1.707 & 2.124 & 1.357 & 0.215 & 0.930 & 2.771 \\
\hline
\end{tabular}

Source: prepared by the authors.

a Total factor productivity. 
FIGURE 4

\section{Cumulative index of change in total productivity}

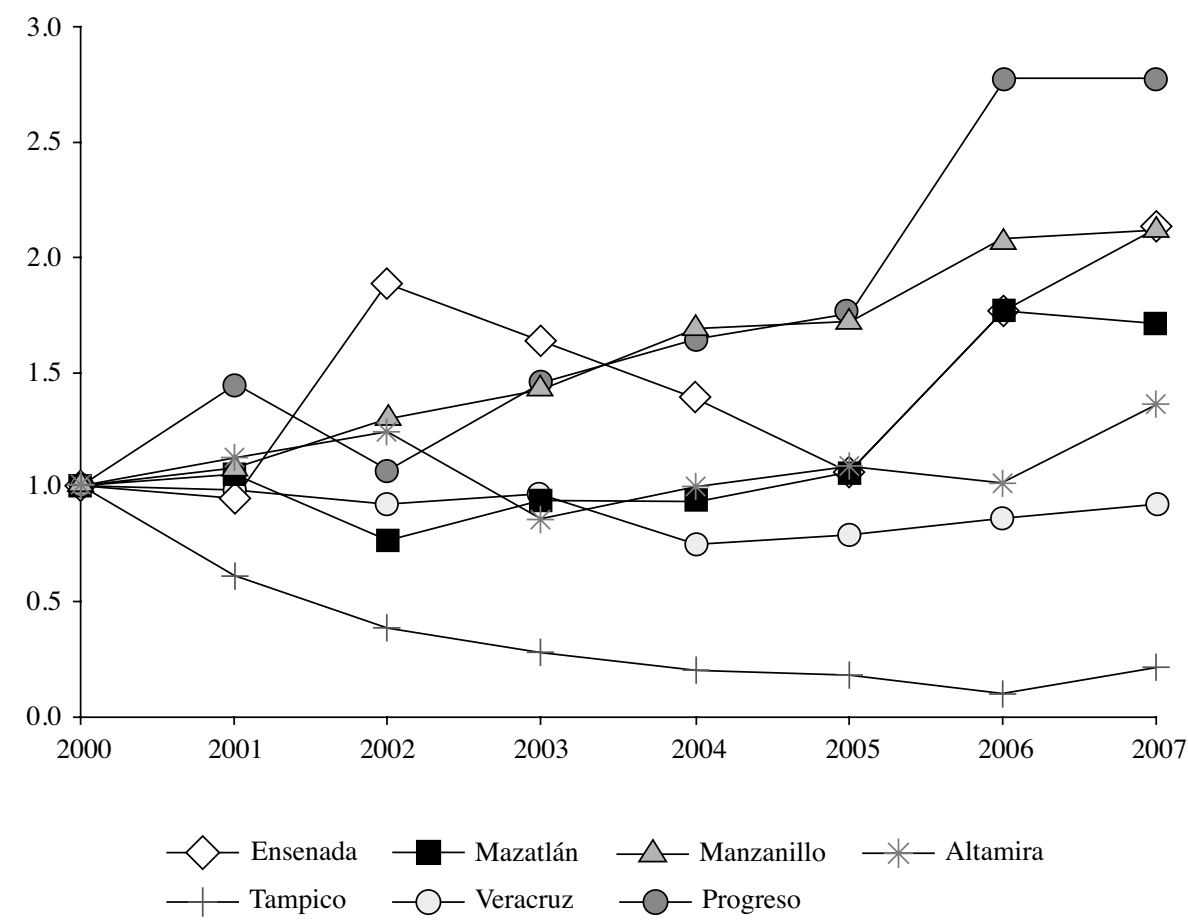

Source: prepared by the authors.

Obtaining the change in each of the components of productivity is important, as this allows us to establish possible reasons for unfavourable changes in total productivity.

Thus, analysis of each of the components of productivity showed that Manzanillo experienced no change in technical efficiency, with the value remaining unchanged at 1 . This was because it was the port that presented the greatest technical efficiency throughout the period analysed; being always at the efficiency frontier, it cannot present an improvement in this factor.

Progreso and Ensenada recorded the greatest changes in technical efficiency. In the efficiency analysis, both Progreso and Ensenada had a low starting value (about 25\% for both ports), while by the end of the period this value had risen to $65 \%$ and $59 \%$ for Progreso and Ensenada, respectively. The opposite is the case at the ports of Veracruz and Tampico, which had high values for technical efficiency at the beginning of the sample but lower values in the later years, most significantly in the case of Tampico. The results of this productivity component are shown in table 3 .
Where changes in production scale are concerned, Ensenada and Progreso once again presented the greatest impact. Ensenada was the port that saw traffic grow the most during the period analysed, from 26,822 TEUs in 2000 to 120,324 in 2007. This substantial increase in production scale meant that the port was closer to achieving an appropriate scale by the end of the sample period.

Progreso did not present a significant increase in its TEU throughput, and the scale of operations at the port may consequently be said to be appropriate, so that a rise in production levels could mean a decline in TFP.

In 2004, Veracruz experienced a decline in both production scale and technical efficiency. This was caused by a falling-off of traffic growth at the port, and by its acquisition of port equipment that year. The values of both components rose after that year, but still finished the period lower than they began it (see tables 4 and 5).

Thus, Veracruz, having been the national leader in container movements up until 2002, not only lost this position to Manzanillo but has lost share in the 
TABLE 3

Cumulative index of change in pure technical efficiency

\begin{tabular}{|c|c|c|c|c|c|c|c|}
\hline Year & Ensenada & Mazatlán & Manzanillo & Altamira & Tampico & Veracruz & Progreso \\
\hline 2000 & 1 & 1 & 1 & 1 & 1 & 1 & 1 \\
\hline 2001 & 0.949 & 1.053 & 1 & 1.125 & 0.609 & 1 & 1.395 \\
\hline 2002 & 2.137 & 0.843 & 1 & 1.180 & 0.415 & 1 & 1.184 \\
\hline 2003 & 1.797 & 1.065 & 1 & 0.905 & 0.324 & 1 & 1.588 \\
\hline 2004 & 1.400 & 0.979 & 1 & 0.965 & 0.212 & 0.713 & 1.653 \\
\hline 2005 & 1.089 & 1.114 & 1 & 1.068 & 0.193 & 0.756 & 1.771 \\
\hline 2006 & 1.773 & 1.828 & 1 & 0.971 & 0.106 & 0.809 & 2.761 \\
\hline 2007 & 2.211 & 1.645 & 1 & 1.180 & 0.208 & 0.894 & 2.468 \\
\hline
\end{tabular}

Source: prepared by the authors.

TABLE 4

Cumulative index of change in production scale efficiency

\begin{tabular}{|c|c|c|c|c|c|c|c|}
\hline Year & Ensenada & Mazatlán & Manzanillo & Altamira & Tampico & Veracruz & Progreso \\
\hline 2000 & 1 & 1 & 1 & 1 & 1 & 1 & 1 \\
\hline 2001 & 0.949 & 1.053 & 1 & 1.074 & 0.609 & 1 & 1.361 \\
\hline 2002 & 2.212 & 0.843 & 1 & 1.127 & 0.415 & 1 & 1.147 \\
\hline 2003 & $1 . .980$ & 1.065 & 1 & 1.026 & 0.324 & 1 & 1.667 \\
\hline 2004 & 1.542 & 0.979 & 1 & 1.044 & 0.212 & 0.983 & 1.735 \\
\hline 2005 & 1.374 & 1.114 & 1 & 1.057 & 0.193 & 0.985 & 1.855 \\
\hline 2006 & 2.126 & 1.828 & 1 & 1.075 & 0.106 & 0.985 & 2.269 \\
\hline 2007 & 2.523 & 1.645 & 1 & 1.127 & 0.208 & 0.995 & 2.171 \\
\hline
\end{tabular}

Source: prepared by the authors.

TABLE 5

Cumulative index of technological change

\begin{tabular}{|c|c|c|c|c|c|c|c|}
\hline Year & Ensenada & Mazatlán & Manzanillo & Altamira & Tampico & Veracruz & Progreso \\
\hline 2000 & 1 & 1 & 1 & 1 & 1 & 1 & 1 \\
\hline 2001 & 1.015 & 1.006 & 1.073 & 1.006 & 1.006 & 1.006 & 1.033 \\
\hline 2002 & 0.883 & 0.906 & 1.297 & 1.047 & 0.934 & 0.921 & 0.906 \\
\hline 2003 & 0.911 & 0.883 & 1.437 & 0.953 & 0.883 & 0.962 & 0.919 \\
\hline 2004 & 0.992 & 0.961 & 1.685 & 1.037 & 0.961 & 1.058 & 0.999 \\
\hline 2005 & 0.981 & 0.950 & 1.717 & 1.025 & 0.950 & 1.047 & 0.988 \\
\hline 2006 & 0.995 & 0.964 & 2.070 & 1.041 & 0.965 & 1.062 & 1.003 \\
\hline 2007 & 0.961 & 1.036 & 2.124 & 1.152 & 1.034 & 1.040 & 1.123 \\
\hline
\end{tabular}

Source: prepared by the authors.

Gulf to Altamira. This is mainly because of physical constraints at Veracruz, with lack of capacity causing it to lose business to Altamira.

The reduction in TEU throughput at Veracruz provides an example of the kind of care that needs to be taken when measuring TFP. Even though the fall-off in traffic may be due to situations unconnected with the port's productivity, the model treats it as an inefficiency, translating into a loss of productivity. To return to the example, there is a widespread perception that Veracruz is more efficient and productive than Altamira, so that if the idea is to analyse port competitiveness the model needs to be strengthened by bringing in extra factors such as service levels, interconnection with other modes of transport, differentiation, etc.

Another limitation of the methodology was detected by Tongzon and Heng (2005), who observed when analysing the productivity of port terminals in 
Europe that both Hamburg and Rotterdam presented low indices of productivity, contrary to customer perceptions. When they came to examine the causes, these authors observed that both ports had made major infrastructure investments. What the model

\section{VI}

\section{Conclusions}

The Malmquist index is a tool that allows changes in total productivity to be determined and decomposed into each of their components. This is important for the implementation of sound strategic planning policies.

Applying the Malmquist index to Mexican ports revealed that the ports of Progreso and Ensenada (whose container throughput is not so significant) were the ones that presented the greatest changes in total factor productivity (TFP), as their superior productivity has enabled them to compete advantageously with the great hub ports and survive the competitive disadvantages they work under.

Of the hubs, Manzanillo is the one that experienced the greatest changes. It was followed by Altamira and Veracruz (the latter experienced a negative change in construed as a loss of productivity, customers of these ports perceived as the opposite.

Consequently, a further line of research would consist in incorporating an analysis of the factors mentioned into the model to avoid erroneous conclusions.
TFP); the two ports compete fiercely to attract flows of goods along the Gulf coast, where Veracruz is beginning to lose ground. It is important for Veracruz to attract larger flows of merchandise to recover the levels of productivity and efficiency it displayed during the early years of the analysis.

The TFP changes obtained leave out some aspects that are important for port productivity, such as service levels, the capacity to adapt to markets and other factors which would be worth analysing to obtain a fuller understanding of port competitiveness.

Another aspect deserving of attention is that while this tool is very useful for calculating productivity, it can be enhanced if supplemented with other strategic planning techniques.

(Original: Spanish)

Bibliography

Aigner, D., C. Lovell and P. Schmidt (1977), "Formulation and estimation of stochastic frontier production function models", Journal of Econometrics, vol. 6, No. 1, Amsterdam, Elsevier.

Caves, D., L. Christensen and W.E. Diewert (1982), "The economic theory of index numbers and the measurement of input, output and productivity", Econometrica, vol. 50, No. 6, New York, Econometric Society.

Charnes, A., W.W. Cooper and E. Rhodes (1978), "Measuring the efficiency of decision-making units", European Journal of Operational Research, vol. 2, No. 6, Amsterdam, Elsevier.

Coelli, T. (1996), "A guide to DEAP version 2.1: a data envelopment analysis (computer) program”, CEPA Working Paper, No. 96/8, Armidale, Departament of Econometrics, University of New England.

Coelli, T., D.S. Prasada Rao and G.E. Battese (1998), An Introduction to Efficiency and Productivity Analysis, Boston, Kluwer Academic Publisher.

Cooper, W.W., L.M. Seiford and K. Tone (2000), Data Envelopment Analysis: A Comprehensive Text with Models, Applications, References and DEA-Solver Software, Boston, Kluwer Academic Publishers.
Coto-Millán, P., J. Baños-Pino and A. Rodríguez-Álvarez (2000), "Economic efficiency in Spanish ports: some empirical evidence", Maritime Policy and Management, vol. 27, No. 2, London, Routledge.

Cullinane, K. and others (2004), "An application of DEA windows analysis to container port production efficiency", Review of Network Economics, vol. 3, $\mathrm{N}^{\circ}$ 2, Canberra, Concept Economics.

Doerr, O. and R. Sánchez (2006), "Indicadores de productividad para la industria portuaria: aplicación en América Latina y el Caribe", Recursos naturales e infraestructura series, No. 112 (LC/L.2578-P), Santiago, Chile, Economic Commission for Latin America and the Caribbean (ECLAC). United Nations publication, Sales No. S.06.II.G.108.

Estache, A., M. González and L. Trujillo (2002), "Efficiency gains from port reform and the potential for yardstick competition: lessons from México", World Development, vol. 30, No. 4, Amsterdam, Elsevier.

Estache, A., B. Tovar de la Fe and L. Trujillo (2004), "Sources of efficiency gains in port reform: a DEA decomposition of a Malmquist TFP index for Mexico", Utilities Policy, vol. 12, No. 4, Amsterdam, Elsevier. 
Fare, R. and others (1994), "Productivity growth, technical progress, and efficiency changes in industrialized countries", American Economic Review, vol. 84, No. 1, Nashville, Tennessee, American Economic Review.

Farell, M.J. (1957), "The measurement of productive efficiency", Journal of the Royal Statistical Society, Series A (General), vol. 120, No. 3, London, Royal Statistical Society.

Fried, H.O., C.A. Lovell and S.S. Schmidt (2008), The Measurement of Productive Efficiency and Productivity Growth, Oxford, Oxford University Press.

González, M.M. (2004), "Eficiencia en la provisión de servicios de infraestructura portuaria: una aplicación al tráfico de contenedores en España", thesis, Las Palmas de Gran Canaria, Universidad de las Palmas de Gran Canaria.

González, M.M. and L. Trujillo (2005), "La medición de la eficiencia en el sistema portuario: revisión de la evidencia empírica", Documento técnico, No. 2005/06, Las Palmas de Gran Canaria, Universidad de Las Palmas de Gran Canaria.

Herrera, S. and G. Pang (2005), "Efficiency of infrastructure: the case of container ports", Washington, D.C., World Bank, draft.

Liu, B.L., W.L. Liu and C.P. Cheng (2006), Efficiency Analysis of Container Terminals in China: an Application of DEA Approach, Tianjin, Nankai University.

Lovell, C.A.K. (1993), "Production frontier and productive efficiency", The Measurement of Productive Efficiency: Techniques and Applications, H. Fried, C.A.K. Lovell and S.S. Schmidt (eds.), Oxford, Oxford University Press.

Marlow, P.B. and A.C. Paixão (2003), "Measuring lean ports performance", International Journal of Transport Management, vol. 1, No. 4, Amsterdam, Elsevier.

Martner, C. (2002), "Hub ports in Mexico: limitations and opportunities", CEPAL Review, No. 76 (LC/G.2175-P), Santiago, Chile.

Maudos, J., J.M. Pastor and L. Serrano (1998), "Convergencia en las regiones españolas: cambio técnico, eficiencia y productividad", Revista española de economía, vol. 15, No. 2, Bilbao, Asociación Española de Economía.

Poitras, G., J. Tongzon and H. Li (1996), "Measuring Port Efficiency: An Application of Data Envelopment Analysis", Singapore, Department of Economics and Statistics, National University of Singapore, unpublished.

Secretaría de Comunicaciones y Transportes (2008), Informe estadístico mensual. Movimiento de buques, carga y pasajeros enero a diciembre 2006-2007, Mexico City, Coordinación General de Puertos y Marina Mercante.

(2007), Manual estadístico del sector transporte, 2006, Mexico City, Mexican Institute of Transport.

(2001), Los puertos mexicanos en cifras 1994-2000, Mexico City, Coordinación General de Puertos y Marina Mercante

(various years), Anuario estadístico del sector comunicaciones y transportes, Mexico City, Coordinación General de Planeación.

Shephard, R.W. (1953), Cost and Production Functions, Princeton, Princeton University Press.

Tongzon, J. and W. Heng (2005), "Port privatization, efficiency and competitiveness: some empirical evidence from container ports (terminals)", Transportation Research Part A, vol. 39, No. 5, Amsterdam, Elsevier.

UNCTAD (United Nations Conference on Trade and Development) (1988), "Medición y evaluación del rendimiento y de la productividad de los puertos", Monografías de la UNCTAD sobre gestión de puertos series, New York.

Van de Voorde, E. and others (2002), Port Competitiveness, Antwerp, Editions De Boeck. 